Article

\title{
Isolation and Antimicrobial Sensitivity of Mycoplasma synoviae and Mycoplasma gallisepticum from Vaccinated Hens in Mexico
}

\author{
Víctor M. Petrone-Garcia ${ }^{1, *(1)}$, Guillermo Tellez-Isaias ${ }^{2}{ }^{\mathbb{D}}$, Fernando Alba-Hurtado ${ }^{3}$, \\ Christine N. Vuong ${ }^{2}$ and Raquel Lopez-Arellano ${ }^{4}$ (I) \\ 1 Programa de Doctorado en Ciencias de la Salud y Producción Animal, Facultad de Estudios Superiores \\ Cuautitlán, Universidad Nacional Autónoma de México, Cuautitlán Izcalli 54714, Mexico \\ 2 Department of Poultry Science, University of Arkansas, Fayetteville, AR 72704, USA; \\ gtellez@uark.edu (G.T.-I.); vuong@uark.edu (C.N.V.) \\ 3 Departamento de Ciencias Biológicas, Facultad de Estudios Superiores Cuautitlán, Universidad Nacional \\ Autónoma de México, Cuautitlán Izcalli 54714, Mexico; fealba@hotmail.com \\ 4 Laboratorio No 5: LEDEFAR, Unidad de Investigación Multidisciplinaria, Facultad de Estudios Superiores \\ Cuautitlán, Universidad Nacional Autónoma de México, Cuautitlán Izcalli 54714, Mexico; \\ lopezar@unam.mx \\ * Correspondence: petrone@unam.mx; Tel.: +52-5524415519
}

Received: 5 October 2020; Accepted: 5 November 2020; Published: 7 November 2020

check for updates

\begin{abstract}
Mycoplasma synoviae (MS) and Mycoplasma gallisepticum (MG) strains were isolated at $39.5^{\circ} \mathrm{C}$ to rule out temperature-sensitive strains (ts+) and identified using random amplification of polymorphic DNA. Then, their minimum inhibitory concentrations $\left(\mathrm{MIC}_{100}\right)$ were calculated in isolated strains from broiler breeders and laying hens vaccinated with ts+ MS-H and ts+ MG TS-11 vaccines in Mexico. We sampled 631 lots of hens. A total of 28 of the 123 MS isolates and 12 of the $23 \mathrm{MG}$ isolates were analyzed using random amplification of polymorphic DNA, of which 24 and 3 matched the DNA banding patterns of the MS-H and MG-F strains, respectively. The isolated MS and MG strains were sensitive to tiamulin and tylosin and showed intermediate sensitivity or resistance to lincomycin, florfenicol, erythromycin, enrofloxacin, and curcumin. Although both the MS and MG strains were sensitive to the same antibiotics $\left(\mathrm{MIC}_{100}\right.$ lower than $1 \mathrm{mg} \mathrm{mL}^{-1}$ ), the $\mathrm{MG}$ strains were 5 to 10 times more sensitive than the MS strains. MS is the most frequently isolated mycoplasma in Mexican poultry production. The MS vaccine used (ts+ MS-H) could reverse its thermosensitivity and therefore could regain its virulence. MS was less sensitive to tiamulin and tylosin compared to MG.
\end{abstract}

Keywords: Mycoplasma synoviae; curcumin; thermosensitivity; pathogenicity; reversal; MS-H vaccine; tiamulin; tylosin

\section{Introduction}

Mycoplasma synoviae (MS) and Mycoplasma gallisepticum (MG) are the most important Mycoplasma species for commercial poultry in Mexico. For decades, these species have been recognized as the cause of chronic respiratory disease (CRD) [1-3]. In addition, they decrease the fertile egg production in broiler breeders, cause late-stage embryonic death, or result in the births of infected chicks that later develop CRD. This disease suppresses the innate immune responses of the respiratory system and predisposes the bird to infection with Escherichia coli, producing complicated CRD (CCRD) [4]. CCRD is responsible for significant economic losses as it causes polyserositis, septicemia, and death in poultry farms as well as seizures at slaughterhouses $[1,2]$. 
In Mexico, mycoplasmosis is currently controlled by vaccination and antibiotic metaphylaxis. The only vaccine used in Mexico against MS is the MS-H strain. The MS-H strain is temperature sensitive (ts+) and was developed through chemical mutagenesis of an Australian field isolate (strain 86079/7NS) [5]. The ts+ MG vaccine strain used in Mexico is TS-11, which was also developed through chemical mutagenesis of an Australian field isolate (strain 80083) [6]. The most widely used groups of antibiotics against Mycoplasma spp. are macrolides, pleuromutilins, lincosamides, and fluoroquinolones. Other antibiotics with poor sensitivity, such as amphenicols and tetracyclines, are mainly used in combination to treat CCRD [7,8]. Because Mycoplasma spp. are primarily vertically transmitted from the hen to the chick, vaccination and treatments mainly focus on broiler breeders.

Considerable efforts have been made to develop more powerful, effective, well-tolerated, and, above all, safe medicines for humans. One of these medicines is curcumin (1, C21H20O6) or diferuloylmethane, which is extracted from the turmeric tuber (Curcuma longa L. Zingiberaceae) [9]. Studies on the in vitro antibacterial effect of curcumin on Staphylococcus aureus, Staphylococcus intermedius, Staphylococcus epidermidis, and Edwardsiella tarda [10] have demonstrated that the minimum inhibitory concentration (MIC) of curcumin solubilized in dimethyl sulfoxide against Mycoplasma spp. isolated from mammals ranges from 50 to $100 \mu \mathrm{g} \mathrm{mL}{ }^{-1}$ [11], although its effect on mycoplasmas isolated from birds has not been demonstrated.

Random amplification of the polymorphic DNA (RAPD) identification method of MS and MG strains has proven efficient and particularly useful for epidemiological studies as well as the identification and differentiation of vaccine strains and field isolates [12-14]. A previous work [15] showed that RAPD had a discriminatory index for MS superior to 0.95 ; consequently, this molecular method was chosen for this study.

Eye or spray vaccination with ts+ MS and MG strains aim to colonize the upper respiratory tract and stimulate the local immune system without causing systemic colonization or transovarian transmission to the progeny. Reversing ts+ to ts-facilitates systemic colonization and transovarian transmission, predisposing the bird to CCRD [16]. Based on the above, the objective of the present study was to isolate and identify ts- vaccine strains from poultry vaccinated with ts+ strains using the RAPD method and evaluate the strains' sensitivity to antimycoplasmic antibiotics.

\section{Results}

In the present study, 631 lots of hens were sampled from 14 poultry companies (Table 1). Mycoplasma spp. were isolated in $23.14 \%(146 / 631)$ of samples from $100 \%(14 / 14)$ of the poultry companies. Of the positive isolates, MS accounted for $84.25 \%(123 / 146)$ of the isolates and was significantly $(p<0.001)$ more frequently isolated than MG, which accounted for $15.75 \%(23 / 146)$ of isolates. Of the 123 MS isolates, 28 were analyzed using RAPD, 24 presented DNA banding patterns matching those of the MS-H strain, and four presented different DNA banding patterns. Of the $23 \mathrm{MG}$ isolates, 12 were analyzed using RAPD, three presented DNA banding patterns matching those of the MG-F strain, and nine were untyped strains with DNA banding patterns different from those of the vaccine control strains (Table 2).

Table 1. Mycoplasma synoviae (MS) and Mycoplasma gallisepticum (MG) isolates in lots of broiler breeders and laying hens in different states of Mexico.

\begin{tabular}{ccccccccccccc}
\hline & \multicolumn{4}{c}{ Broiler Breeders } & \multicolumn{4}{c}{ Laying Hens } & Total Hens \\
\hline & Ags & Chis & SoM & Jal & Qro & Ver & Total & Jal & Pue & Total \\
\hline Sampled lots & 6 & 52 & 102 & 90 & 84 & 57 & 391 & 37 & 203 & 240 & 631 \\
M. synoviae & 2 & 15 & 16 & 26 & 9 & 32 & 100 & 7 & 16 & 23 & 123 \\
M. gallisepticum & 2 & 0 & 14 & 0 & 6 & 1 & 23 & 0 & 0 & 0 & 23 \\
\hline
\end{tabular}

Ags = Aguascalientes; Chis = Chiapas; SoM = State of Mexico, Jal = Jalisco, Qro = Querétaro, Ver = Veracruz, and Pue = Puebla. 
Table 2. The RAPD identification of Mycoplasma synoviae and Mycoplasma gallisepticum vaccine strains isolated at $39.5^{\circ} \mathrm{C}$ in broiler breeders and laying hens in different states of Mexico.

\begin{tabular}{ccccccccc}
\hline & Ags & Chi & SoM & Jal & Pue & Qro & Ver & Total \\
\hline MS-H strain & 2 & 5 & - & 5 & 6 & 1 & 5 & 24 \\
Untyped M. synoviae & 0 & 0 & - & 3 & 1 & 0 & 0 & 4 \\
MG-F strain & 2 & - & 0 & - & - & - & 1 & 3 \\
Untyped $M$. gallisepticum & 0 & - & 9 & - & - & - & 9 & 9 \\
\hline
\end{tabular}

RAPD = Random amplification of polymorphic DNA. Ags = Aguascalientes; Chi = Chiapas; $\mathrm{SoM}=$ State of Mexico, $\mathrm{Jal}=$ Jalisco, Pue $=$ Puebla, Qro $=$ Querétaro, and Ver $=$ Veracruz.

MS isolates were susceptible to tiamulin and tylosin but resistant to curcumin, erythromycin, and florfenicol. The MG isolates were susceptible to erythromycin, tiamulin, and tylosin (Table 3).

Table 3. The mean \pm standard deviation in $\mu \mathrm{g} \mathrm{mL}^{-1}$ of the minimum inhibitory concentration $\left(\mathrm{MIC}_{100}\right)$ of Mycoplasma synoviae and M. gallisepticum isolates from broiler breeders and laying hens in Mexico.

\begin{tabular}{|c|c|c|c|c|c|c|c|}
\hline & Curcumin * & Enrofloxacin & Erythromycin & Florfenicol & Lincomycin & Tiamulin & Tylosin \\
\hline M. synoviae & $\begin{array}{c}\geq 2.50 \pm 0.00 \\
\mathrm{a}(\mathrm{R})\end{array}$ & $\begin{array}{c}1.64 \pm 0.74 \\
\mathrm{a}(\mathrm{I})\end{array}$ & $\begin{array}{l}\geq 2.50 \pm 0.00 \\
\quad \mathrm{~b}(\mathrm{R})\end{array}$ & $\begin{array}{c}2.23 \pm 0.52 \\
\mathrm{a}(\mathrm{R})\end{array}$ & $\begin{array}{c}1.81 \pm 0.66 \\
\mathrm{a}(\mathrm{I})\end{array}$ & $\begin{array}{c}0.43 \pm 0.30 \\
\mathrm{~b}_{(\mathrm{S})}\end{array}$ & $\begin{array}{c}0.92 \pm 0.41 \\
\mathrm{~b}(\mathrm{I})\end{array}$ \\
\hline M. gallisepticum & $\begin{array}{c}\geq 2.50 \pm 0.00 \\
\mathrm{a}(\mathrm{R})\end{array}$ & $\begin{array}{c}1.90 \pm 1.09 \\
\mathrm{a}(\mathrm{I})\end{array}$ & $0.48 \pm 0.78^{\mathrm{a}}(\mathrm{S})$ & $\begin{array}{c}\geq 2.50 \pm \\
0.00^{\mathrm{b}}(\mathrm{R})\end{array}$ & $\begin{array}{c}\geq 2.50 \pm 0.00 \\
\mathrm{~b}_{(\mathrm{R})}\end{array}$ & $\begin{array}{c}0.03 \pm 0.02 \\
\mathrm{a}(\mathrm{S})\end{array}$ & $\begin{array}{c}0.07 \pm 0.05 \\
\mathrm{a}(\mathrm{S})\end{array}$ \\
\hline
\end{tabular}

* Five isolates of each Mycoplasma species were used for curcumin. Different letters between the same antibiotic indicate significant differences $(p<0.05) . \quad R=$ resistant isolates, $\mathrm{I}=$ isolates with intermediate sensitivity, and $\mathrm{S}=$ sensitive isolates.

The isolates with DNA banding patterns matching those of the MS-H strain, the isolates that presented different patterns, and the ts+ MS-H vaccine strain (control) were all susceptible to tiamulin and tylosin and were resistant to curcumin, florfenicol, and erythromycin (Table 4). The isolates with DNA banding patterns matching those of the MG-F strain and MG-F vaccine strain (control) were susceptible to enrofloxacin, tiamulin, and tylosin but resistant to curcumin, florfenicol, and lincomycin. The isolates with DNA banding patterns matching those of untyped MG strains and the ts+ TS-11 vaccine strain (control) were sensitive to erythromycin, tiamulin, and tylosin but resistant to curcumin, enrofloxacin, florfenicol, and lincomycin (Table 5).

Table 4. The means \pm standard deviation in $\mu \mathrm{g} \mathrm{mL}^{-1}$ of the minimum inhibitory concentration ( $\mathrm{MIC}_{100}$ ) of Mycoplasma synoviae isolates by DNA banding pattern in hens in Mexico.

\begin{tabular}{|c|c|c|c|c|c|c|c|}
\hline & Curcumin & Enrofloxacin & Erythromycin & Florfenicol & Lincomycin & Tiamulin & Tylosin \\
\hline ts- MS-H & $\begin{array}{c}\geq 2.50 \pm 0.00 \\
\quad \mathrm{a}(\mathrm{R})\end{array}$ & $\begin{array}{c}1.72 \pm 0.70 \\
\mathrm{~b}_{(\mathrm{I})}\end{array}$ & $\begin{array}{c}\geq 2.50 \pm 0.00 \\
{ }^{a}(\mathrm{R})\end{array}$ & $\begin{array}{c}2.19 \pm 0.55 \\
\mathrm{a}(\mathrm{R})\end{array}$ & $\begin{array}{c}1.80 \pm 0.67 \\
\mathrm{~b}(\mathrm{I})\end{array}$ & $\begin{array}{c}0.45 \pm 0.31 \\
\mathrm{a}(\mathrm{S})\end{array}$ & $\begin{array}{c}0.95 \pm 0.41 \\
\mathrm{~b}_{(\mathrm{S})}\end{array}$ \\
\hline $\begin{array}{l}\text { Untyped } \\
\text { M. synoviae }\end{array}$ & $\begin{array}{c}\geq 2.50 \pm 0.00 \\
\quad \mathrm{a}(\mathrm{R})\end{array}$ & $\begin{array}{c}1.17 \pm 0.97 \\
\mathrm{~b}_{(\mathrm{I})}\end{array}$ & $\begin{array}{c}\geq 2.50 \pm 0.00 \\
\quad \mathrm{a}(\mathrm{R})\end{array}$ & $\begin{array}{c}\geq 2.50 \pm \\
0.00^{\mathrm{a}}(\mathrm{R})\end{array}$ & $\begin{array}{c}1.88 \pm 0.72 \\
\mathrm{~b}(\mathrm{I})\end{array}$ & $\begin{array}{c}0.31 \pm 0.22 \\
\quad \mathrm{a}(\mathrm{S})\end{array}$ & $\begin{array}{c}0.70 \pm 0.39 \\
\mathrm{~b}_{(\mathrm{S})}\end{array}$ \\
\hline ts+ MS-H & $\begin{array}{c}\geq 2.50 \pm 0.00 \\
\quad \mathrm{a}(\mathrm{R})\end{array}$ & $\begin{array}{c}0.31 \pm 0.00 \\
\quad \mathrm{a}(\mathrm{S})\end{array}$ & $\begin{array}{c}\geq 2.50 \pm 0.00 \\
\quad \mathrm{a}(\mathrm{R})\end{array}$ & $\begin{array}{c}\geq 2.50 \pm \\
0.00^{\mathrm{a}}(\mathrm{R})\end{array}$ & $\begin{array}{c}0.63 \pm 0.00 \\
{ }^{a}(S)\end{array}$ & $\begin{array}{c}0.08 \pm 0.00 \\
{ }^{a}(S)\end{array}$ & $\begin{array}{c}0.02 \pm 0.00 \\
{ }^{a}(S)\end{array}$ \\
\hline
\end{tabular}

Five isolates of each Mycoplasma species were used for curcumin. Different letters between the same antibiotic indicate significant differences $(p<0.05)$. $\mathrm{R}=$ resistant isolates, $\mathrm{I}=$ isolates with intermediate sensitivity, and $\mathrm{S}=$ sensitive isolates. 
Table 5. The means \pm standard deviation in $\mu \mathrm{g} \mathrm{mL}^{-1}$ of the minimum inhibitory concentration ( $\mathrm{MIC}_{100}$ ) of Mycoplasma gallisepticum isolates by DNA banding pattern in hens in Mexico.

\begin{tabular}{|c|c|c|c|c|c|c|c|}
\hline & Curcumin & Enrofloxacin & Erythromycin & Florfenicol & Lincomycin & Tiamulin & Tylosin \\
\hline MG-F strain & $\begin{array}{c}\geq 2.50 \pm 0.00 \\
\quad \mathrm{a}(\mathrm{R})\end{array}$ & $\begin{array}{c}0.08 \pm 0.00 \\
{ }^{a}(S)\end{array}$ & $1.67 \pm 0.72^{\mathrm{a}}(\mathrm{I})$ & $\begin{array}{c}\geq 2.50 \pm \\
0.00^{\mathrm{b}}(\mathrm{R})\end{array}$ & $\begin{array}{c}\geq 2.50 \pm 0.00 \\
\mathrm{a}_{(\mathrm{R})}\end{array}$ & $\begin{array}{c}0.05 \pm 0.02 \\
\mathrm{a}(\mathrm{S})\end{array}$ & $\begin{array}{c}0.04 \pm 0.00 \\
\mathrm{a}_{(\mathrm{S})}\end{array}$ \\
\hline $\begin{array}{l}\text { Untyped } M \text {. } \\
\text { gallisepticum }\end{array}$ & $\begin{array}{l}\geq 2.50 \pm 0.00 \\
{ }_{\mathrm{a}}(\mathrm{R})\end{array}$ & $\begin{array}{l}\geq 2.50 \pm 0.00 \\
{ }^{C}(\mathrm{R})\end{array}$ & $0.08 \pm 0.05^{\mathrm{b}}(\mathrm{S})$ & $\begin{array}{c}\geq 2.50 \pm \\
0.00^{\mathrm{b}}(\mathrm{R})\end{array}$ & $\begin{array}{c}\geq 2.50 \pm 0.00 \\
{ }_{\text {a }}(\mathrm{R})\end{array}$ & $\begin{array}{c}0.02 \pm 0.01 \\
\mathrm{a}(\mathrm{S})\end{array}$ & $\begin{array}{c}0.08 \pm 0.05 \\
{ }^{a}(S)\end{array}$ \\
\hline MG-F strain & $\begin{array}{c}\geq 2.50 \pm 0.00 \\
\quad \mathrm{a}(\mathrm{R})\end{array}$ & $\begin{array}{c}0.08 \pm 0.00 \\
\text { a (S) }\end{array}$ & $0.01 \pm 0.00^{\mathrm{c}}(\mathrm{S})$ & $\begin{array}{c}\geq 2.50 \pm \\
0.00^{\mathrm{b}}(\mathrm{R})\end{array}$ & $\begin{array}{l}\geq 2.50 \pm 0.00 \\
\quad \text { a (R) }\end{array}$ & $\begin{array}{c}0.01 \pm 0.00 \\
{ }^{a}(S)\end{array}$ & $\begin{array}{c}0.01 \pm 0.00 \\
{ }^{a}(S)\end{array}$ \\
\hline $\begin{array}{l}\text { ts }+ \text { MG } \\
\text { TS-11 }\end{array}$ & $\begin{array}{c}\geq 2.50 \pm 0.00 \\
{ }^{a}(\mathrm{R})\end{array}$ & $\begin{array}{c}0.39 \pm 0.00 \\
\mathrm{~b}(\mathrm{~S})\end{array}$ & $0.01 \pm 0.00^{\mathrm{c}}(\mathrm{S})$ & $\begin{array}{c}0.62 \pm 0.00 \\
\mathrm{a}(\mathrm{S})\end{array}$ & $\begin{array}{c}\geq 2.50 \pm 0.00 \\
{ }^{a}(\mathrm{R})\end{array}$ & $\begin{array}{c}0.01 \pm 0.00 \\
\mathrm{a}(\mathrm{S})\end{array}$ & $\begin{array}{c}0.01 \pm 0.00 \\
\mathrm{a}(\mathrm{S})\end{array}$ \\
\hline
\end{tabular}

Five isolates of each Mycoplasma species were used for curcumin. Different letters between the same antibiotic indicate significant differences $(p<0.05)$. $\mathrm{R}=$ resistant isolates, $\mathrm{I}=$ isolates with intermediate sensitivity, and $\mathrm{S}=$ sensitive isolates.

\section{Discussion}

CRD and CCRD are two diseases that commonly affect poultry production in Mexico and many other parts of the world. One of the main forms of control is vaccination with live strains of MS and MG that do not grow at $39.5^{\circ} \mathrm{C}$ or higher temperatures because vaccinating with strains unable to reproduce at body temperature prevents vaccine strain mycoplasmas from causing sepsis or transmitting to the egg. In this study, from laying hens previously vaccinated with the ts+ MS-H strain, we isolated MS at $39.5^{\circ} \mathrm{C}$ with DNA banding patterns identical to those of the ts+ MS-H vaccine strain; therefore, in some cases, the ts+ strains were able to revert their $39.5^{\circ} \mathrm{C}$ thermosensitivity and reproduce in hens.

We found a higher rate of MS than MG isolates in both types of hens (broiler breeders and laying hens), most likely owing to the highly technical poultry industry in Mexico, as was also found in highly developed poultry farming countries in Europe and in the Americas [17-22]. In Europe, state-led MG eradication programs have been implemented [21]. In the Americas, the USA has a voluntary testing and certification program for flocks free of both mycoplasmas, while in the rest of the continent, control programs aimed at biosecurity with mycoplasma-free birds or mycoplasmosis control with antibiotic metaphylaxis are voluntary for private poultry farmers [1,23]. Additionally, in this study, we observed that MG was 5 to 10 times more sensitive than MS to two of the world's most widely used antibiotics in the poultry industry (tiamulin and tylosin); therefore, with the use of the same dose of antibiotic treatment, the likelihood of eliminating MG is higher than that of eliminating MS.

A ts $+\left(39.5^{\circ} \mathrm{C}\right)$ vaccine strain that reverses its sensitivity may reproduce in birds and cause $C R D$ as well as transmit to the progeny. Thermosensitivity reversal in ts $+\mathrm{MS}-\mathrm{H}$ strains has been demonstrated by isolating strains typed as MS-H at $39.5^{\circ} \mathrm{C}$ using restriction fragment length polymorphism analysis in broiler breeders and laying hens [5]. Under laboratory conditions, without performing molecular tests, it was shown that this thermosensitivity reversal was not a complete reversion to virulence when the ts- MS-H were isolated from lesions in specific-pathogen-free pullets (SPAFAS) [16]. In our study, using RAPD, we isolated and identified MS-H strains that grew at $39.5^{\circ} \mathrm{C}$ exclusively from tracheal samples of broiler breeder and laying hens.

The samples were obtained from egg-producing hens vaccinated with the ts+ MS-H strain between two and four weeks of age, suggesting that the MS-H strain reversed thermosensitivity after 16 to 25 weeks of application. Therefore, isolated ts- MS-H strains can cause MS contamination in eggs, reducing egg production and causing economic loss. In broiler breeders, MS transmission to their progeny could cause CRD and mortality in broilers. Due to these disorders, it is essential to consider the possible risk of a reversal of pathogenicity when applying the ts+ MS-H strain or other live ts+ vaccines against Mycoplasma spp. In specific-pathogen-free hens vaccinated under laboratory conditions, Armour and Ferguson-Noel [24] and El Gazzar et al. [25] demonstrated that the ts+ MG TS-11 strain could revert its thermosensitivity and pathogenicity, cause septicemia, and invade the ovary, thus infecting the eggs. 
In our study, of the 12 isolated and characterized MG strains, no strain showed DNA banding patterns matching those of the ts+ MG TS-11 strain; as a result, we were unable to demonstrate that they reversed their thermosensitivity. In our study, we found three MG strains whose DNA banding patterns matched those of the F strain, which was originally a vaccine strain; currently, the F strain can be considered a vaccine or field strain, with nine strains corresponding to untyped wild-type field strains. In the study by Armour and Ferguson-Noel [24], vaccine mycoplasmas failed to colonize bird tissues; however, under field conditions, as in our study, wild strains can compete for receptors of target cells with the vaccine strain TS-11. Most likely, this competition is one of the reasons why this strain was not isolated successfully.

In Mexico, and in many other countries, CRD is controlled with vaccines and antibiotic metaphylaxis; accordingly, the sensitivity to different antibiotics must be periodically assessed by region and by country. Our findings showed that our Mycoplasma isolates, in general, were of intermediate sensitivity or resistant to lincomycin, florfenicol, erythromycin, enrofloxacin, and curcumin. The Mycoplasma isolates, both untyped wild type and vaccine strains, were only sensitive to tiamulin and tylosin. The majority of studies on antimycoplasmic effects were performed with MG [7]; however, the $\mathrm{MIC}_{100}$ for MG is lower than that for MS. Thus, effective control of both Mycoplasma species requires using a dose 3 to 5 times higher than that needed to control MS. Regarding erythromycin, we agree with the work of Gautier-Bouchardon [26], which states that MS is inherently resistant to the antibiotic while MG is not.

In the search for new drugs that are effective against bacteria and safe for the environment as well as for humans, well-characterized products of plant origin, including polyphenols, such as curcumin, have been evaluated. Curcumin previously exhibited an antimycoplasmic effect against Mycoplasma hominis, Mycoplasma capricolum, Mycoplasma mycoides, Mycoplasma genitalium, and Mycoplasma pneumoniae at concentrations ranging from 50 to $100 \mu \mathrm{gL}^{-1}$ [11]. We considered the strains that grew at a dilution greater than $2 \mu \mathrm{g} \mathrm{mL}^{-1}$ as resistant to Mycoplasma. In this study, all MS and MG strains grew at $2.5 \mu \mathrm{g} \mathrm{mL}^{-1}$, which was the maximum concentration, showing that curcumin was ineffective against MS and MG at the concentrations economically profitable for poultry production.

\section{Materials and Methods}

\subsection{Sampled Farms}

The present study was conducted from January 2010 to December 2019. Samples were collected from 14 poultry companies with a medical history of CRD in their hens or chicks (eight broiler breeders and four laying hens). Samples of broiler breeders were collected from the following Mexican states: Jalisco, Querétaro, Aguascalientes, State of Mexico, Chiapas, and Veracruz. Samples of laying hens were collected from the following Mexican states: Jalisco and Puebla.

\section{Farm Selection Criteria}

Broiler breeder farms whose progeny had a history of serosal-fibrinous airsacculitis or fibrinous arthritis were selected for this study, whereas the selected laying hen farms had a history of hens with airsacculitis or peritonitis and low egg production ranging from $2 \%$ to $10 \%$. The hens of the selected farms were previously vaccinated against MS using live strain ts+ MS-H (Vaxsafe ${ }^{\circledR}$ MS, Laboratorio Avimex, Mexico City, Mexico) and against MG with one of the two live strains ts+ TS-11 (TS-11 ${ }^{\circledR}$, Boehringer Ingelheim Vetmedica, Guadalajara, Mexico) or strain F (F VAX-MG ${ }^{\circledR}$, MSD Animal Health, Mexico City, Mexico).

\subsection{Bacterial Isolation}

In total, 10 hens were randomly selected from each farm. Tracheal scrapping samples were collected using a swab and transported in FREY liquid medium. The samples were incubated at $39.5^{\circ} \mathrm{C}$ for 20 days $[27,28]$. Cultures were reviewed daily, and subcultures of samples showing changes in the 
$\mathrm{pH}$ were prepared according to the method described by Poveda [29]. The cultures that showed no change in $\mathrm{pH}$ were considered negative. MS and MG were identified in biochemical tests (glucose fermentation, tetrazolium reduction, arginine hydrolysis, and digitonin sensitivity), and the results were confirmed with direct immunofluorescence testing. Cloning was completed by aspirating single colonies with a Pasteur pipette and inoculating broth medium to eliminate clumped cells and then re-plating on agar. The cultures were cloned three times to ensure purity. After sufficient growth in broth, the medium was filtered through a $0.45 \mu \mathrm{M}$ filter to eliminate clumped cells and re-plated on agar, as described by Poveda [29] and Ferguson-Noel and Kleven [30]. To serve as controls, original strains of the MS-H and TS- 11 vaccines were incubated at $33^{\circ} \mathrm{C}$, and the $\mathrm{F}$ strain was incubated at $37^{\circ} \mathrm{C}$.

\subsection{Molecular Identification of Mycoplasma spp. Vaccine Strains}

The DNA of isolated and cloned MS and MG strains was identified by RAPD using the technique and primers designed by Geary et al. [31]. The DNA banding patterns of the isolated strains were compared to the DNA banding patterns of the MS-H, MG-F, and MG TS-11 reference strains.

\subsection{In Vitro Sensitivity to Antibiotics and Curcumin}

$\mathrm{MIC}_{100}$ of six antibiotics and curcumin $\left(1, \mathrm{C}_{21} \mathrm{H}_{20} \mathrm{O}_{6}\right)$ was calculated with the isolated Mycoplasma strains. The antibiotics evaluated in this study were selected based on widespread usage in poultry in Mexico for mycoplasma control and classification as critically important for both veterinary and human use by the World Health Organization [32]. The following antibiotics were obtained from Merck (Kenilworth, NJ, USA): lincomycin hydrochloride, florfenicol, erythromycin thiocyanate, enrofloxacin, tiamulin hydrogen fumarate, and tylosin tartrate. Polyphenol 4.5\% curcumin (Laboratorios Mixim, Public Limited Company, Naucalpan, Mexico) was chemically dispersed into polyvinyl pyrollidone (Plastone K-29/32, Ashland ${ }^{\mathrm{TM}}$, Mexico City, Mexico). The dilutions were calculated in relation to the final concentration of the base molecule. $\mathrm{MIC}_{100}$ values were defined as the lowest concentration of the antibiotic at which $100 \%$ of the isolates were inhibited.

All isolated strains were assayed for antibiotic $\mathrm{MIC}_{100}$, whereas only five strains from each Mycoplasma were evaluated against curcumin. MIC $_{100}$ was calculated according to the method described by Hannan [33] using FREY culture medium [27,29]. Following the recommendation of Hannan [33], the culture concentration of each isolated Mycoplasma spp. was adjusted to $10^{4}$ color changing units $\mathrm{mL}^{-1}$, with phenol red as the indicator. Two-fold dilutions of the antibiotic were prepared, ranging from 2.5 to $0.01 \mu \mathrm{g} \mathrm{mL} \mathrm{m}^{-1}$, although there are no official cut-off points for the interpretation of $\mathrm{MIC}_{100}$ for avian mycoplasma [26,33]. In this investigation, isolates were considered susceptible to antibiotics when the $\mathrm{MIC}_{100}$ was $0.5 \mathrm{~g} \mathrm{~mL}^{-1}$. Isolates with $\mathrm{MIC}_{100} 1 \mathrm{~g} \mathrm{~mL}^{-1}$ were classified as intermediate to antibiotics and those with $\mathrm{MIC}_{100} 2 \mathrm{~g} \mathrm{~mL}^{-1}$ were classified as resistant. These criteria were adapted from the research of Lysnyansky et al. [34].

\subsection{Statistical Analysis}

The proportion of the number of isolates was compared using the chi-squared test. The mean $\mathrm{MIC}_{100}$ of each antibiotic was compared between MS and MG isolates using Student's $t$-test. An analysis of variance (ANOVA) was performed on the $\mathrm{MIC}_{100}$ results of the same antibiotic from typified strains (based on DNA banding pattern), and the differences between the means were evaluated using Tukey's honestly significant difference (HSD) test. Statistical significance was set at $p<0.05$.

\subsection{Ethical Compliance}

This study was conducted in accordance with the recommendations of the Institutional Animal Care and Use Committee (IACUC) at the University of Arkansas (Fayetteville, AR, USA) under approved protocol \#17073. 


\section{Conclusions}

Based on the findings of this study, we propose that MS is the most important Mycoplasma for Mexican poultry production for the following reasons: MS was the Mycoplasma species most frequently isolated, the vaccine used (ts+ MS-H) was able to revert its temperature sensitivity and recover virulence, and MS was 5 to 10 times less sensitive than MG to the most widely used antibiotics (tiamulin and tylosin). Further studies evaluating the virulence of these thermosensitive revertant strains on egg production and on the progeny of hens vaccinated with MS-H are necessary to determine the economic and health impact of this reversal.

Author Contributions: Conceptualization, V.M.P.-G. and G.T.-I.; methodology, V.M.P.-G. and G.T.-I.; software, V.M.P.-G.; validation, R.L.-A. and F.A.-H.; formal analysis, V.M.P.-G.; investigation, V.M.P.-G. and G.T.-I.; resources, G.T.-I. and V.M.P.-G.; data curation, V.M.P.-G.; writing—original draft preparation, V.M.P.-G. and F.A.-H.; writing-review and editing, R.L.-A. and G.T.-I.; visualization, C.N.V.; supervision, R.L.-A. and F.A.-H.; project administration, G.T.-I. and R.L.-A.; funding acquisition, G.T.-I., R.L.-A., and V.M.P.-G. All authors have read and agreed to the published version of the manuscript.

Funding: This research received no external funding.

Acknowledgments: This research was supported by the Arkansas Bioscience Institute under the following project: Development of an avian model for evaluation early enteric microbial colonization on the gastrointestinal tract and immune function. The research also obtained funding from the PAPIIT IT201620 project of DGAPA-UNAM, Universidad Nacional Autónoma de México. The authors thank CONACyT for the doctoral grant number 494367.

Conflicts of Interest: The authors declare no conflict of interest.

\section{References}

1. Ferguson-Noel, N.; Noormohammadi, A.H. Mycoplasma synoviae Infection. In Diseases of Poultry; Swayne, D.E., Glisson, J.R., McDougald, L.R., Nolan, L.K., Suarez, D.L., Nair, V., Eds.; John Wiley \& Sons, Inc.: Ames, IA, USA, 2013; pp. 900-906, ISBN 978-0-470-95899-5.

2. Raviv, Z.; Ley, D.H. Mycoplasma gallisepticum Infection. In Diseases of Poultry; Swayne, D.E., Glisson, J.R., McDougald, L.R., Nolan, L.K., Suarez, D.L., Nair, V., Eds.; John Wiley \& Sons, Inc.: Ames, IA, USA, 2013; pp. 877-893, ISBN 978-0-470-95899-5.

3. Kursa, O.; Pakuła, A.; Tomczyk, G.; Paśko, S.; Sawicka, A. Eggshell apex abnormalities caused by two different Mycoplasma synoviae genotypes and evaluation of eggshell anomalies by full-field optical coherence tomography. BMC Vet. Res. 2019, 15, 1. [CrossRef] [PubMed]

4. Awad, N.F.S.; Abd El-Hamid, M.I.; Hashem, Y.M.; Erfan, A.M.; Abdelrahman, B.A.; Mahmoud, H.I. Impact of single and mixed infections with Escherichia coli and Mycoplasma gallisepticum on Newcastle disease virus vaccine performance in broiler chickens: An in vivo perspective. J. Appl. Microbiol. 2019, 127, 396-405. [CrossRef] [PubMed]

5. Markham, J.F.; Morrow, C.J.; Scott, P.C.; Whithear, K.G. Safety of a Temperature-Sensitive Clone of Mycoplasma synoviae as a Live Vaccine. Avian Dis. 1998, 42, 677. [CrossRef] [PubMed]

6. Whithear, K.; Soeripto; Harringan, K.; Ghiocas, E. Safety of temperature sensitive mutant Mycoplasma gallisepticum vaccine. Aust. Vet. J. 1990, 67, 159-165. [CrossRef] [PubMed]

7. Jordan, F.T.; Forrester, C.A.; Ripley, P.H.; Burch, D.G. In vitro and in vivo comparisons of valnemulin, tiamulin, tylosin, enrofloxacin, and lincomycin/spectinomycin against Mycoplasma gallisepticum. Avian Dis. 1998, 42, 738-745. [CrossRef]

8. Hofacre, C.L.; Fricke, J.A.; Inglis, T. Antimicrobial Drug Use in Poultry. In Antimicrobial Therapy in Veterinary Medicine; Giguère, S., Prescott, J.F., Dowling, P.M., Eds.; Wiley Blackwell: Ames, IA, USA, 2013; pp. 569-587, ISBN 978-0-470-96302-9.

9. Ammon, H.; Wahl, M. Pharmacology of Curcuma longa. Planta Med. 1991, 57, 1-7. [CrossRef] [PubMed]

10. Lawhavinit, O.; Kongkathip, N.; Kongkathip, B. Antimicrobial activity of curcuminoids from Curcuma longa L. on pathogenic bacteria of shrimp and chicken. Kasetsart J. Nat. Sci. 2010, 44, 364-371.

11. Boeder, A.M.; Tenfen, A.; Siebert, D.A.; de Almeida, C.L.B.; Firmo, C.R.M.; Scharf, D.R.; Micke, G.A.; Siminionatto, E.L.; de Cordova, C.M.M.; Guedes, A. Anti-mycoplasma activity of Curcuma longa extracts and your isolated compound, the curcumin. Rev. Fitos 2018, 12. [CrossRef] 
12. Charlton, B.R.; Bickford, A.A.; Walker, R.L.; Yamamoto, R. Complementary Randomly Amplified Polymorphic DNA (RAPD) Analysis Patterns and Primer Sets to Differentiate Mycoplasma Gallisepticum Strains. J. Vet. Diagn. Investig. 1999, 11, 158-161. [CrossRef]

13. Fan, H.H.; Kleven, S.H.; Jackwood, M.W. Application of Polymerase Chain Reaction with Arbitrary Primers to Strain Identification of Mycoplasma gallisepticum. Avian Dis. 1995, 39, 729. [CrossRef]

14. Fan, H.H.; Kleven, S.H.; Jackwood, M.W. Studies of Intraspecies Heterogeneity of Mycoplasma synoviae, M. meleagridis, and M. iowae with Arbitrarily Primed Polymerase Chain Reaction. Avian Dis. 1995, $39,766$. [CrossRef]

15. Marois, C.; Dufour-Gesbert, F.; Kempf, I. Comparison of pulsed-field gel electrophoresis with random amplified polymorphic DNA for typing of Mycoplasma synoviae. Vet. Microbiol. 2001, 79, 1-9. [CrossRef]

16. Noormohammadi, A.H.; Jones, J.F.; Harrigan, K.E.; Whithear, K.G. Evaluation of the Non-Temperature-Sensitive Field Clonal Isolates of the Mycoplasma synoviae Vaccine Strain MS-H. Avian Dis. 2003, 47, 355-360. [CrossRef]

17. King, D.D.; Kleven, S.H.; Wenger, D.M.; Anderson, D.P. Field Studies with Mycoplasma synoviae. Avian Dis. 1973, 17, 722. [CrossRef] [PubMed]

18. Buim, M.R.; Mettifogo, E.; Timenetsky, J.; Kleven, S.; Ferreira, A.J.P. Epidemiological survey on Mycoplasma gallisepticum and M. synoviae by multiplex PCR in commercial poultry. Pesqui. Veterinária Bras. 2009, 29, 552-556. [CrossRef]

19. Kapetanov, M.; Orlić, D.; Potkonjak, D.; Velhner, M.; Stojanov, I.; Milanov, D.; Stojanovic, D. Mycoplasma in poultry flocks in the year 2009 compared to the year 2000 and significance of the control measures. Lucr. Ştiintifice Med. Vet. 2010, 43, 249-253.

20. Yilmaz, F.; Timurkaan, N. Detection of Mycoplasma gallisepticum and Mycoplasma synoviae Antigens by Immunohistochemical Method in Pneumonic Broiler Chicken Lungs. J. Anim. Vet. Adv. 2011, 10, 2557-2560. [CrossRef]

21. Landman, W.J.M. Is Mycoplasma synoviae outrunning Mycoplasma gallisepticum? A viewpoint from the Netherlands. Avian Pathol. 2014, 43, 2-8. [CrossRef]

22. Michiels, T.; Welby, S.; Vanrobaeys, M.; Quinet, C.; Rouffaer, L.; Lens, L.; Martel, A.; Butaye, P. Prevalence of Mycoplasma gallisepticum and Mycoplasma synoviae in commercial poultry, racing pigeons and wild birds in Belgium. Avian Pathol. 2016, 45, 244-252. [CrossRef]

23. United States Department of Agriculture National Poultry Improvement Plan (NPIP). Available online: https://www.aphis.usda.gov/aphis/ourfocus/animalhealth/nvap/NVAP-Reference-Guide/Poultry/ National-Poultry-Improvement-Plan (accessed on 14 September 2020).

24. Armour, N.K.; Ferguson-Noel, N. Evaluation of the egg transmission and pathogenicity of Mycoplasma gallisepticum isolates genotyped as ts-11. Avian Pathol. 2015, 44, 296-304. [CrossRef]

25. El Gazzar, M.; Laibinis, V.A.; Ferguson-Noel, N. Characterization of a ts-11-like Mycoplasma gallisepticum Isolate from Commercial Broiler Chickens. Avian Dis. 2011, 55, 569-574. [CrossRef] [PubMed]

26. Gautier-Bouchardon, A.V. Antimicrobial Resistance in Mycoplasma spp. In Antimicrobial Resistance in Bacteria from Livestock and Companion Animals; Schwarz, S., Cavaco, L.M., Shen, J., Eds.; American Society of Microbiology: Washington, DC, USA, 2018; pp. 425-446, ISBN 978-1-55581-979-8.

27. Jordan, F.T.W. Recovery and Identification of avian Mycoplasmas. In Methods in Mycoplasmology; Tully, J.G., Razin, S., Eds.; Elsevier: New York, NY, USA, 1983; Volume II, pp. 69-79, ISBN 978-0-12-583802-3.

28. Sader, H.S. Antimicrobial resistence in Latin America. How are we? Rev. Chil. Infectol. 2002, 19, S5-S13. [CrossRef]

29. Poveda, J.B. Biochemical Characteristics in Mycoplasma Identification. In Mycoplasma Protocols; Miles, R., Nicholas, R., Eds.; Humana Press: Totowa, NJ, USA, 1998; pp. 69-78, ISBN 978-0-89603-525-6.

30. Ferguson-Noel, N.; Kleven, S.H. Mycoplasma Species. In A Laboratory Manual, the Isolation, Identification and Characterization of Avian Pathogens; Williams, S.M., Dufour-Zavala, L., Jackwood, W.M., Lee, M.D., Lupiani, B., Reed, W.M., Spackman, E., Woolcock, P.R., Eds.; American Association of Avian Pathologists: Jacksonville, FL, USA, 2016; pp. 63-70, ISBN 978-0-9789163-7-4.

31. Geary, S.J.; Forsyth, M.H.; Saoud, S.A.; Wang, G.; Berg, D.E.; Berg, C.M. Mycoplasma gallisepticum strain differentiation by arbitrary primer PCR (RAPD) fingerprinting. Mol. Cell. Probes 1994, 8, 311-316. [CrossRef] [PubMed] 
32. Food and Agriculture Organization of the United Nations; World Health Organization; International Office of Epizootics (Eds.) Joint FAO/WHO/OIE Expert Meeting on Critically Important Antimicrobials: Report of the FAO/WHO/OIE Expert Meeting, FAO Headquarters, Rome, Italy, 26-30 November 2007; Food and Agriculture Organization of the United Nations: Rome, Italy, 2008; ISBN 978-92-5-106009-4.

33. Hannan, P.C.T. Guidelines and recommendations for antimicrobial minimum inhibitory concentration (MIC) testing against veterinary mycoplasma species. Vet. Res. 2000, 31, 373-395. [CrossRef] [PubMed]

34. Lysnyansky, I.; Gerchman, I.; Mikula, I.; Gobbo, F.; Catania, S.; Levisohn, S. Molecular Characterization of Acquired Enrofloxacin Resistance in Mycoplasma synoviae Field Isolates. Antimicrob. Agents Chemother. 2013, 57, 3072-3077. [CrossRef]

Publisher's Note: MDPI stays neutral with regard to jurisdictional claims in published maps and institutional affiliations.

(C) 2020 by the authors. Licensee MDPI, Basel, Switzerland. This article is an open access article distributed under the terms and conditions of the Creative Commons Attribution (CC BY) license (http://creativecommons.org/licenses/by/4.0/). 